\title{
sciendo
}

\author{
Current Issues in Pharmacy and Medical Sciences
}

Formerly ANNALES UNIVERSITATIS MARIAE CURIE-SKLODOWSKA, SECTIO DDD, PHARMACIA

\section{Diagnosis of human cytomegvirus association with malignant gliomas and pro- and anti-inflammatories}

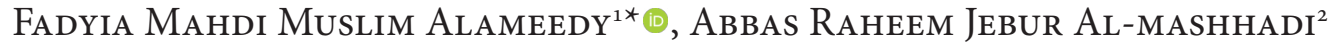 \\ ${ }^{1}$ Faculty of Science, Kufa University, Najaf, Iraq \\ 2 Faculity of Medicine, Kufa University, Najaf, Iraq \\ ARTICLE INFO \\ Received 23 February 2019 \\ Accepted 12 March 2019

\section{Keywords:} \\ CMV, \\ ICAM, \\ SPSS, \\ RT-PCR.

\begin{abstract}
The study was conducted on seventy individuals of both genders who have been exposed to human cytomegalovirus, a common illness in Iraq. Total cases of human cytomegvirus associated with malignant brain tumors were detected by a real time PCR technique. This resulted in only thirty-six cases of true infection. Of these 24 cases were female, while 12 cases of male infected. The titer to assay the presence of anti- and pro-inflammatories was assessed in sera of all patients by using ELISA kits to evaluate cytokines. This indicated that the pro-inflammatory IL12, after seven days increased $(1.67 \pm 0.23 \mathrm{pg} / \mathrm{ml})$, while IL4, an anti-inflammatory, decreased to reach $(0.39 \pm 0.16 \mathrm{pg} / \mathrm{ml})($ at $\mathrm{p}<0.05)$ in the plasm of the experimental patients compared with the control group.
\end{abstract}

\section{INTRODUCTION}

After major contagion with human Cytomegalovirus (CMV), the virus be latent in manifold members, only to be invigorated through vital dysregulation of the immune system [1]. Monocytes develop into macrophages when in inflammatory surroundings such as after operation, in situations of pain, sepsis and burns, and viral reproduction begins [2]. CMV infection is not observed in monocyte form $[3,4]$. CMV has a large genome of about $235 \mathrm{~kb}$, and contains more than 200 genes. Furthermore, it shows icosahedral regularity [1].

Taher et al. (2013) has demonstrated the prevalence of CMVt in the stomachs of $70-80 \%$ of the world's people, with no difference seen in gender, age and public \& private living conditions [5]. Kaveh (2010) states that human cytomegalovirus is not renowned as an oncogenic virus, but it might raise the virulence of infected cells by disrupting cellular ways, entangling the cell cycle, enhancing cell infestation, and interfering with angiogenesis and apoptosis immunal responses [6].

Malignant gliomas are the majority of mutual elementary brain tumors in adults, have no known etiology, and are mostly quickly fatal, regardless of immerse therapies. HCMV gene products can dysregulate multiple cellular trails implicated in oncogenesis and HCMV can be invigorated in conditions of injury and immunosuppression [7].

\footnotetext{
* Corresponding author

e-mail: fadyiam.alameedy@uokufa.edu.iq
}

Interleukin-12 is naturally produced in response to antigenic stimulation and blocks the development of new blood vessels, but stimulates the growth and function of T-cells and aid in the targeting of abnormal cell forms aids. IL-12 is generated in response to inflammation, hence, is a proinflammatory [8]. IL-4 plays essential roles in a myriad of cellular actions, especially in chronic inflammation and wound repair. It also plays an important role in tumour progression. Il-4 is considered an anti-inflammatory $[9,10]$.

\section{MATERIAL AND METHODS}

Samples of human Cytomegalovirus were collected from sufferers of various ages and both genders with malignant brain tumors. Real time PCR was utilized to screen the virus, resulting in (direct primer), [5'-GTCAGCGTTCGTGTTTCCCA-3'; pp812] and (reverse primer), [5'-GGGACACAACACCGTAAAGC-3'] [11]. Appraisal of cytokine content was by way of ELISA kits of [cat. Number KAC1561 and KHC0041, Invitrogen Corporation]. The "Statistical package for social science": (SPSS) blueprint (version-19) was used in statistical assessment.

\section{RESULTS}

Thirty-six individuals showed positive for infection (Fig. 1, 2), as specified by "real time PCR". The presence of pro-inflammatory IL-12 top titer $(1.67 \pm 0.23,1.54 \pm 0.26$, $1.48 \pm 0.28 \mathrm{pg} / \mathrm{ml})$ was then compared to that of the 


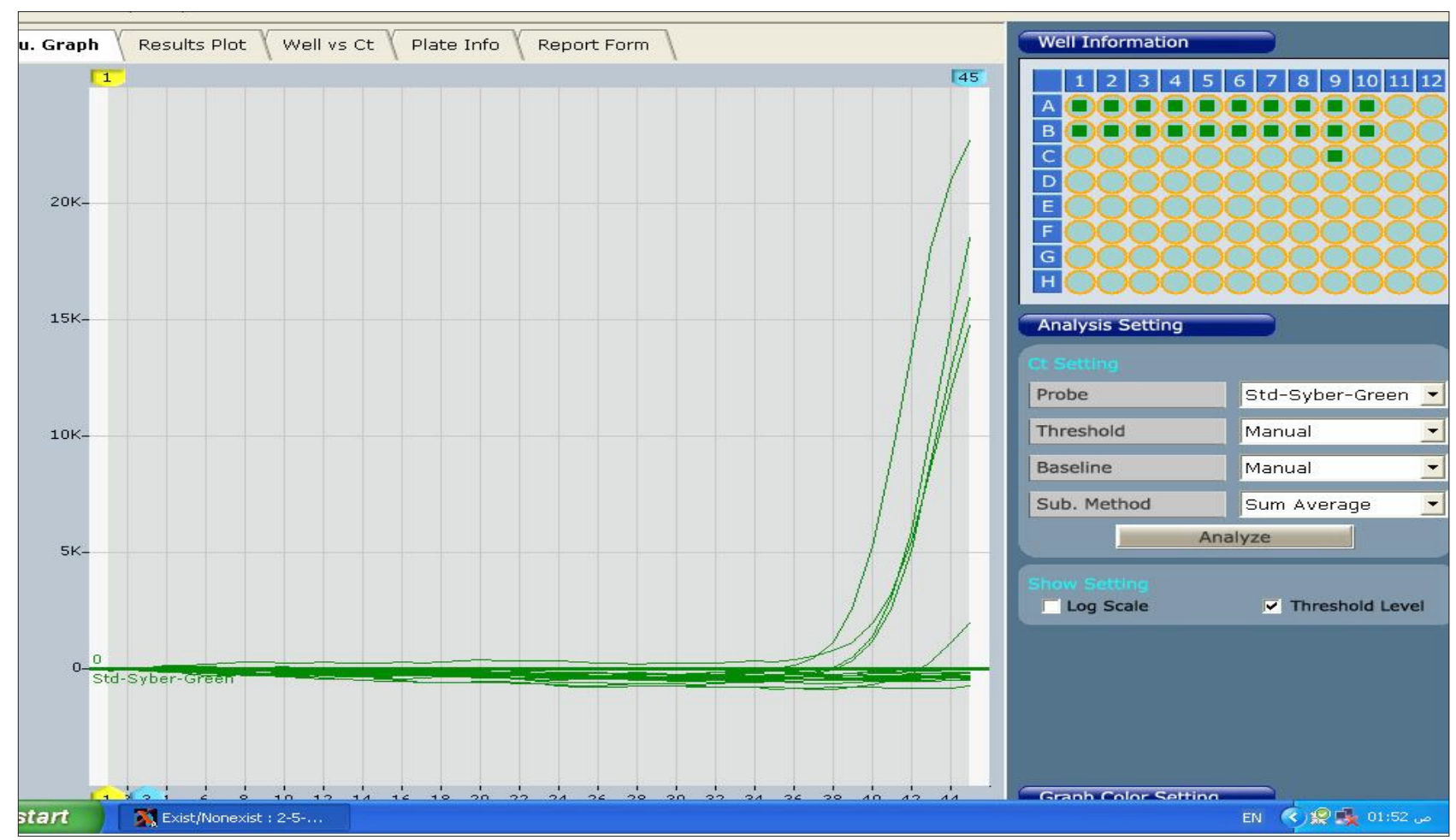

Figure 1. Diagnosis of human cytomegalovirusby quantitative real time reverse transcriptase PCR

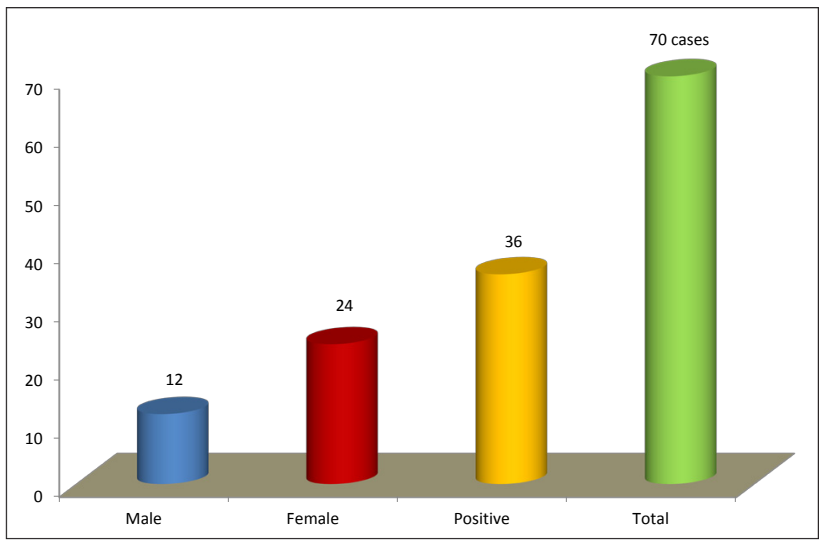

Figure 2. Total of cases human cytomegalovirus with malignant gliomas

anti-inflammatory IL-4 $(0.39 \pm 0.16,0.31 \pm 0.25,0.29 \pm 0.27$ $\mathrm{pg} / \mathrm{ml}$ ) from one week up to three weeks consecutively in comparison with the oversight value of $(0.78 \pm 0.19$ $\mathrm{pg} / \mathrm{ml})$ (Table1).

Table 1. Evaluation Cytokines of of Human Cytomegvirus association with malignant gliomas

\begin{tabular}{|l|c|c|c|c|}
\hline \multicolumn{1}{|c|}{ Cytokines } & $\begin{array}{c}\text { Groups } \\
\text { and number }\end{array}$ & 7 day & 14 day & 21 day \\
\hline $\begin{array}{l}\text { Pro-inflammatory } \\
\text { IL-12 }\end{array}$ & $\begin{array}{c}\text { Infected } \\
\text { (n.36) }\end{array}$ & $1.67 \pm 0.23$ & $1.54 \pm 0.26$ & $1.48 \pm 0.28$ \\
\hline $\begin{array}{l}\text { Ant-inflammatory } \\
\text { IL-4 }\end{array}$ & $\begin{array}{c}\text { Infected } \\
\text { (n.36) }\end{array}$ & $0.39 \pm 0.16$ & $0.31 \pm 0.25$ & $0.29 \pm 0.27$ \\
\hline Control & $\begin{array}{c}\text { Healthy human } \\
\text { (n.15) }\end{array}$ & $0.78 \pm 0.19$ & $0.78 \pm 0.19$ & $0.78 \pm 0.19$ \\
\hline
\end{tabular}

\section{DISCUSSION}

Our results conform with that existent by the Iraqi Cancer Registry [12], but do not correspond with the proportion amounted to females $(46.66 \%)$ and to males $(23.33 \%)$, the corresponding figures. Our results also conform with those of Brousset et al. [13] in linking human cytomegalovirus with malignant gliomas. El-Zein et al. [14] and Udai et al. [15] also educed an apparent relationship with the development of gliomas, despite disparities in the percentage of tumor cells. The results in quantitative screening via real time reverse transcriptase PCR are acceptable with that of the study of Sampson et al. [16]. In our work, in extending the application of PCR into assessing viral DNA, revelation of human cytomegvirus came about through utilizing blood samples and demonstrated realization in the infected groups.

Our study of the presence of pro- and anti- inflammatories was the first to occur in Iraq in the quest to see linkage between the virus and the disease. Herein, our study showed that levels of IL-4 decrease, while IL-12 increase with the development of brain tumour. This corresponds with the studies reported in [20-22].

\section{CONCLUSIONS}

1. Relationship exists between the presence of the virus and disease.

2. Change can be seen in the level of pro- and antiinflammatories.

\section{ACKNOWLEDGMENTS}

To the staff of the Oncology Center and to the doctors, as well as all the appreciation of the patients. We wish them a quick recovery.

\section{ORCID iDs}

Fadyia Alameedy (1)https://orcid.org/0000-0002-8868-5926 


\section{REFERENCES}

1. Crough T, Khanna R. Immunobiology of human cytomegalovirus: from bench to bedside. Clin Microbiol Rev. 2009;22:76-98.

2. Hummel M, Abecassis MM. A model for reactivation of CMV from latency. J Clin Virol. 2002;25:123-36.

3. MC Guedes MI, Risdahl JM, Wiseman B, Molitor TW. Reactivation of porcine cytomegalovirus through allogeneic stimulation. J Clin Microbiol. 2004;42:1756-8.

4. Muller LV, Klemn A, Weiss M, Schneider M, Sugar-Wiedeck H, Durmus N, et al. Active cytomegalovirus infection in patients with septic shock. Emerg Infect Dis. 2006;12:1517-22.

5. Taher C, de Boniface J, Mohammad AA, Religa P, Hartman J, Yaiw KC, et al. High prevalence of human cytomegalovirus proteins and nucleic acids in primary breast cancer and metastatic sentinel lymph nodes. PLos One. 2013;10:1371-7.

6. Kaveh B. Oncomodulatory mechanism of HCMV in glioma. J Clin Neurosci. 2010;17:819-23.

7. Samanta M, Harkins L, Cobbs CS, Yancey Gillespie G, Bharara S, King PH, et al. Human cytomegalovirus infection and expression in human malignant glioma. Cancer Res. 2002;62(12):3347-50.

8. Joki T, Kikuchi T, Akasaki Y, Saitoh S, Abe T, Ohno T. Induction of effective antitumor immunity in a mouse brain tumor model using B7-1(CD80) and intercellular adhesive molecule 1 (ICAM-1; CD54) transfection and recombinant interleukin 12. Int J Cancer. 1999;82:714.

9. Michelucci A, Heurtaux T, Grandbarbe L, Morga E, Heuschling P. Characterization of the microglial phenotype under specific pro-inflammatory and anti-inflammatory conditions: Effects of oligomeric and fibrillar amyloid-beta. J Neuroimmunol. 2009;210:3-12.

10. Howard M, Farrar J, Hilfiker M, Johnson B, Takatsu K, Hamaoka $\mathrm{T}$, Paul WE. Identification of a T cell-derived $\mathrm{b}$ cell growth factor distinct from interleukin 2. J Exp Med. 1982;155:914-23
11. Antoine GC, Jean CN, Chahrazed B, Axelle D, Yanne M, Elyanne G. Quantification of Human Cytomegalovirus DNA by Real-Time PCR. J Clin Microbiol. 2001;39(2) 772-5.

12. Iraqi Cancer Registry; 2005

13. Brousset P, Delisle MB, Trémoulet M, Allart S, Labrousse F, Pommepuy I, Uro-Coste E. Detection of human cytomegalovirus genome and gene products in central nervous system tumours. Brit J Cancer. 2005;92:747-50.

14. El-Zein R, Albrecht T, Aldape KD, Bondy ML, Scheurer ME. Detection of human cytomegalovirus in different histological types of gliomas. Acta Neuropathol. 2008;116(1):79-86.

15. Udai PS, Haider SK, Aws RH, Abdulameer K, Dennis DT, Robert LP, et al. Detection of human cytomegalovirus in different histopathological types of glioma in Iraqi patients. Hindawi Publishing Corporation. BioMed Res Int. 2015;10.

16. Sampson JH, Mitchell DA, Xie W, Schmittling R, Learn C, Friedman A, McLendon RE. Sensitive detection of human cytomegalovirus in tumors and peripheral blood of patients diagnosed with glioblastoma. Neuro-Oncology. 2008;10(1):10-8.

17. Puri KR, Varricchio F, Prayson AR, Joshi BH, Leland P, Asher A. In situ expression of interleukin-4 (IL-4) receptors in human brain tumors and cytotoxicity of a recombinant IL- 4 cytotoxin in primary glioblastoma cell cultures. Cancer Res. 2001;61:8058-61.

18. Kranz MD, Webb AG. IL-12 Treatment of Endogenously Arising. J Immunol. 2016;165:7293-9.

19. Kipnis J, Norris T, Cronk CJ, Gadani SP. IL-4 in the brain. J Immunol. 2016;189:4213-9.

20. Puri KR, Varricchio F, Prayson AR, Joshi BH, Leland P, Asher A. In situ expression of interleukin-4 (IL-4) receptors in human brain tumors and cytotoxicity of a recombinant IL- 4 cytotoxin in primary glioblastoma cell cultures. Cancer Res. 2001;61:8058-61.

21. Kranz MD, Webb AG. IL-12 Treatment of endogenously arising. J Immunol. 2016;165:7293-9.

22. Kipnis J, Norris T, Cronk CJ, Gadani SP. IL-4 in the brain. J Immunol. 2016;189:4213-9. 